\title{
MORE THAN ARCHAEOLOGY: NEW DIRECTIONS IN CULTURAL HERITAGE MANAGEMENT
}

\author{
ANNE ROSS \\ Department of Anthropology and Sociology \\ and Department of Natural and Rural Systems Management, \\ The University of Queensland, Queensland 4072
}

\begin{abstract}
Cultural heritage management (CHM) has long been regarded as an off-shoot of mainstream archaeology, largely because CHM began as a result of archaeological concerns about the destruction of sites by amateur fossicking and urban development pressures (Bowdler 1983, Cleere 1989).

The archaeological paradigm which underpinned CHM has recently been challenged, largely as a result of Aboriginal involvement in decision making (Byrne 1991, Sullivan 1993, Ellis 1994, Ross 1996). Focus has moved away from the 'site'; landscapes are becoming the unit of management and the roles of anthropology and indigenous ascription of meaning to place are growing rapidly as the new basis for CHM. These shifts and their implications for heritage management authorities and academic researchers are examined.
\end{abstract}

\section{Introduction}

At nearly every Australian Archaeological Association (AAA) conference for the past 10 years there have been sessions on Cultural Resources Management or 'CRM'. The emphasis has largely been on the need for, or the results of, aspects of archaeological research generated by consulting projects or on the need for greater cooperation between heritage practitioners (and archaeologists in general) and the indigenous community. In the latter case the call has usually been for Aboriginal people to have a greater involvement in decision-making about the management of their heritage.

There have been two changes to the practice of CRM which I believe are largely a result of these sessions at AAA conferences, backed up by similar sessions at workshops hosted by the CRM industry in general (the Australian Association of Consulting Archaeologists Inc. [AACA], museums and regulatory authorities). The first change is that CRM has moved from being primarily a 'dots on maps', site recording, inventory-based discipline (Bowdler 1981), to one which is more rigorous in its archaeological approaches to survey and site excavation. For example, regulatory authorities such as the New South Wales National Parks and Wildlife Service (NSW NPWS) and Queensland Department of Environment (QDoE) now require detailed research designs based on current archaeological method and theory before permits to excavate sites ahead of development projects are granted. In Queensland, where permits to survey are also required, a detailed archaeological methodology for the survey stage of investigation is also a requirement of the permitting policy (Rob Neal, QDoE pers. comm.).

The second change relates to Aboriginal consultation policy. This has affected archaeological practice generally, not just that within the area of CRM. Policies requiring consultation with Aboriginal communities about site management and site research of any kind are now commonplace. Members of AACA and AAA, for example, must now agree to adhere to such policies when they join these organisations. Aboriginal consultation has been made a mandatory component of all Aboriginal site based CRM projects by most regulatory authorities in Australia. Reports which do not adequately address this part of a study may be rejected by the authority. Furthermore, in the Department of Anthropology and Sociology at the University of Queensland a policy on ethics for anthropological and archaeological research is currently being developed and all staff and students in the Department will be required to abide by this code, which is to incorporate cooperation and liaison with indigenous communities in both seeking permission for research and undertaking research.

Each of these changes has had important ramifications for CRM practice. Nevertheless, despite the positive moves toward greater involvement of Aboriginal people in heritage management, and perhaps because of the more rigorous archaeological approaches to CRM, the practice is still very much focussed on archaeological rather than Aboriginal concerns. The need to more closely address indigenous concerns regarding indigenous heritage is the subject of this paper.

\section{Cultural Resources and Cultural Heritage Management}

'Cultural resources management' is a North American term, coined in the 1960s to describe the work of archaeologists who implement the relics protection legislation (Cleere 1989). A 'resource' is a physical entity; something which supplies a need. The dictionary defines it as 'a source of support', and 'a source of economic wealth'. Consequently we often tend to think of resources, both natural and cultural, in financial or 
economic terms. Cultural Resources Management is therefore a term which emphasises a manager's task of identification and analysis of the physical remains of the past. The 'central purpose' of the Federal Archaeology Program in the United States, for example, is 'managing the nation's archaeological heritage in the interests of the public' (Rogers and McManamon 1994:4, emphasis added).

'Heritage', on the other hand, is defined as something 'transmitted from the past' or 'handed down by tradition'. It is regarded as something of value, often beyond monetary worth. Furthermore it is not something which is necessarily bounded in either space or time. Although 'transmitted from the past', it is something which also exists in the present. Heritage may also incorporate nonphysical elements of our culture, such as a way of life. The way people collect shellfish or hunt dugongs or retouch rock art is part of their cultural make-up. These elements are included in the concept of cultural heritage but would not be considered cultural 'resources' by many people, largely because these elements are not related to archaeology, which is the dominant paradigm of heritage management practice (see below).

The term 'cultural resources', which replaced 'relics' and is occasionally used as a synonym for 'cultural heritage' in the archaeological lexicon, ... suggests unconscious assumptions of potential use and ownership. 'Heritage' however, sits uncomfortably with the archaeological paradigm and marks the first conscious public challenge to its dominance (Ellis 1994: 18).

In this paper I will use the terminology 'cultural heritage management' rather than cultural resources management, as CHM better reflects the new direction that heritage management is taking.

\section{CHM and the Archaeological Paradigm}

In Australia the earliest legislation designed to protect places of heritage value focussed on Aboriginal archaeological sites and relics.

This archaeological bias was not surprising, in view of the strong lobbying and input into the legislation by archaeologists concerned at the threat of damage or loss of sites from amateur unscientific research, private collectors and development pressures (Flood 1989:80).

Laws to protect other forms of Aboriginal heritage, such as sacred sites and story places, have been slow to follow. In many states there is still no legislation which adequately caters for the protection of nonarchaeological places of significance to Aboriginal and Torres Strait Islander people. In New South Wales, for example, only 'relics' receive automatic protection under the National Parks and Wildlife Act 1974. Places of significance to Aboriginal people which have no physical evidence of their association with Aboriginal culture, can only be protected following gazettal, which requires detailed documentation, reference to other interested parties and Ministerial approval (Sullivan 1986). Furthermore, there is no provision in the legislation for formal input into decision-making by Aboriginal people although consultation is a requirement of current policy. Aboriginal people have indicated that this is far from adequate involvement (Geering and Roberts 1993, Task Force Report 1988).

In Queensland the Aboriginal Relics Preservation Act 1967 had similar limitations to the NSW legislation. This Act has now been replaced by the Cultural Record Randscapes Queensland \& Queensland Estate) Act 1987. As the title of this new Act implies, landscapes are identified as places which can be protected under the provisions of this Act. 'Landscapes Queensland' are defined in Section 5 of the Act as:

areas or features within Queensland that -

a) have been or are being used, altered or affected in some way by man; and

b) are of significance to man for any anthropological, cultural, historic, prehistoric or societal reason,

and includes any item of Queensland Estate

[sites] found therein.

Yet despite this provision, there have been no registrations of 'landscapes' other than anthropologically significant sites (definition ' $b$ ' above) on the Queensland Sites Register under this category (R. Ellis QDoE pers. comm.). Archaeological consultants regularly record items of the Queensland Estate (i.e. archaeological sites) for registration and anthropological sites which are bounded entities are also recorded. But landscapes which contain a number of sites or which have been altered in some way by Aboriginal activity (such as fire or resource management) and are therefore 'Landscapes Queensland' under definition 'a' are rarely documented. On the two occasions I am aware of that such places were proposed for listing, QDoE cultural heritage managers indicated that such areas could not be managed given the nature of the proposed development and insisted upon specific archaeological site recordings only.

These two examples of legislative and bureaucratic restrictions on recording heritage landscapes highlights the constraints of the archaeological paradigm in which CHM operates, at least in the two states with which I am familiar.

The need for cultural heritage management to shake off the constraining shackles of cultural imperialism generated by the dominance of the archaeological paradigm which currently rules CHM has been strongly argued by Sullivan (1993). Given that 'the assertion of cultural identity is...inseparable from cultural heritage' (Makagiansar 1989:9), Sullivan's likening of CHM to imperialism is justified. Archaeology and western ideology have controlled the CHM agenda by analysing and interpreting indigenous heritage to fit a western view of culture. As a result indigenous heritage owners have been effectively disempowered (Langford 1983, Lehman 1991). 
...[O]ur definition and categorisation of cultural heritage management has elements of cultural imperialism which give us problems in the conservation, and promotion of cultural values, and especially in the integration of living traditions into our cultural heritage management policy and strategies (Sullivan 1993:55).

Ellis (1994) has also argued that the framework of cultural heritage management is dominated by the archaeological paradigm. He argues that as the majority of heritage managers in this country are archaeologists, the focus of heritage management has, until very recently, been the 'site' - an element of the landscape which is bounded in both space and time:

The archaeologist is primarily concerned with relocating earlier reported places for detailed systematic investigation, not with the interpretation of cultural landscape values, or cultural amenity, for protection and management purposes ... Archaeology has little concern for the perceptions of Aboriginal custodians about the interrelationship of places or the characteristics of places which impart a 'sense of place' and cultural heritage significance ... [T] he various elements which together constituted the cultural unity of places of community importance were fragmented into separate archaeological dot recordings depicting separate isolated 'sites' (Ellis 1994:16-17).

\section{Landscapes and Sites}

This dichotomy between the importance of 'place' (landscapes) and 'sites' is at the heart of the new directions being taken in CHM. Other writers, including members of indigenous communities, have also emphasised the difference between the western concept of heritage as a specific locale in a broader natural landscape, and the indigenous concept of heritage 'which emphasizes that humankind is not separate from the landscape but is part of an indivisible whole, i.e. heritage as an everyday lived experience' (Hall and McArthur 1993:4).

The following statements from Aboriginal authors demonstrate the concern many Aboriginal people feel about this issue:

\section{Jerringa Land Claim}

Our sites on Beecroft Peninsula should not be considered individually. They are all connected together and should be seen as a whole. Taken together, they make the Peninsula a very spiritual and powerful place.

Because all the sites are connected together, if one site or its surrounding is interfered with, then the whole area suffers. Desertification of any part of Beecroft Peninsula seriously threatens the meaning and spirituality of the whole area.
Not many non-Aboriginal people fully understand how closely our sites and the natural environment are tied together. In fact, they are practically one and the same thing (cited in Stevens 1991:14).

\section{Anangu heritage}

This country has always been the home of Anangu. We survive today because our traditional lands give us strength and purpose ... Anangu will always celebrate and respect the spiritual identity that Uluru gives.

Anangu culture is based upon the relationships between people, plants, animals and the physical features upon the land. Knowledge of how those relationships came to be, what they mean and how we must maintain them, are all explained by our religion ... the Tjukurpa.

...The Tjukurpa is the foundation of Anangu. It provides the rules for behaviour and for living together. It is the Law for caring for one another and for the land that supports our existence.

Life and Land are One ... We have no need for special buildings to remind us of our religion or Law. The Tjukurpa is all around us in the landscape itself...

To see Uluru through Anangu eyes, is to see a complex religious and ceremonial stage. Uluru's many features are very important because they are evidence that the ancestral beings of the Tjukurpa are still with us. Their Law is kept strong in our hearts and minds every day we live here. This is why we have a responsibility to keep our land and our cultural traditions alive. Our past, our present, and our future depend upon it (Mutitjulu Community, 1990: original emphasis).

\section{Mootwingee}

To us, the history and spirituality of a place is more important than the art itself. If the ant is destroyed by natural processes, this does not destroy the importance of the place to us, only to white people. We feel it is more important to protect the surrounding landscape and associated sites than to preserve the art by ugly gridding etc. This is why we find it so sad that there is no shortage of funds for white people to painstaking[ly] record the art or date it, but where is the money to record what our old people know about Mootwingee? (Bates 1993:65).

\section{Discussion}

These statements highlight other concepts of Aboriginal heritage, additional to the importance of landscapes, which are also rarely considered by cultural heritage managers. The notion that heritage is part of a lived and living culture is one of these.

Cultural heritage practitioners and the archaeological community generally were probably first made fully aware of this concept in 1986 when the Ngarinyin Aboriginal community in the Kimberley repainted some 
Wandjina ant figures (Mowaljarli and Peck 1987, Mowaljarli et al. 1988). For many archaeologists and cultural heritage managers (and I include myself here) the initial reaction to this event was one of concern (Horton 1987, Mulvaney 1991). This is because, as Ray Kelly (NPWS Aboriginal Senior Sites Officer pers. comm.) so aptly summarised, archaeology only values things from the past. 'To you archaeologists culture stopped in 1788. You can't recognise that for us Kooris our culture continues now, and into the future'.

After reflection, many (if not most) archaeologists and heritage managers recognised the justification of repainting of art sites as a perpetuation of a living cultural tradition, which is unarguably of greater significance to Aboriginal people than is the fossilisation of culture, which is the way of archaeology (Bowdler 1988).

The repainting debate allowed archaeologists and cultural heritage managers to take part in a debate about the non-physical components of heritage (cf. Makagiansar 1989). Yet heritage managers have rarely moved beyond this example. This, I believe, is because of the archaeological domination of CHM. The issue of repainting rock art had a direct consequence for archaeology. But other equally important issues of living cultural heritage have largely been ignored by cultural heritage managers. It is anthropology that has taken up the primary debates relating to living culture, for example in regard to arguments over the traditional hunting rights of indigenous peoples (e.g. Cordell 1991, 1993, Lewis 1992, 1993, Williams and Hunn [eds] 1993). Nevertheless these are cultural heritage issues (Ross 1994) - although they are not necessarily archaeology.

Despite the fact that most archaeologists regard issues of living cultural heritage as peripheral to their discipline, many of these issues do in fact have implications for archaeological practice. For example, Shelley Greer (1994), working on Cape York Peninsula, has demonstrated that archaeological sites, even those which are disturbed, 'are embedded in a social landscape'. She has documented the stories that are associated with sites and which incorporate sites into cosmological knowledge. To the Injinoo there is a relationship between archaeological sites and the continuity of stories, beliefs and practices which underlies identity. Sites are devices which revive the memory of the past. Sites are sources of empowerment and excavation is a form of appropriation.

\section{CHM Implications}

The implications of this discussion for CHM and its future may be profound. Aboriginal concerns regarding heritage management are unlikely to ever be fully addressed while heritage managers remain tied to an entirely archaeological and site-based approach to CHM. Aboriginal consultation, which seeks Aboriginal endorsement of archaeological management strategies for sites, is unlikely to be regarded as sufficient by
Aboriginal people in this post-Mabo era and CHM will be in danger of becoming irrelevant:

The recent High Court decision concerning the claim of the Meriam people to native title has the potential to have a profound effect upon the operation of heritage agencies. No longer will 'dots on maps' suffice as an adequate response to possible indigenous rights and interests in places ... Custodian data is already essential in negotiation over land use. This is evident in the types of inquiries addressed to agencies in states where land rights legislation is enacted, particularly from land management bodies such as National Parks administrators or from resource developers. As before, heritage systems developed within the archaeological paradigm have no useful information which might systematically address this issue. In short, cultural heritage management in this state [Queensland] is already, because of its historical preoccupations, in danger of irrelevance (Ellis 1994:21).

There are other advantages in broadening the CHM base, too. I will provide two practical examples.

In 1983 the Mutawintji community in western New South Wales blockaded the Mootwingee Historic Site in Mootwingee National Park. The main concerns of the community were that important Aboriginal sites were open to the general public and that the landscape of the Historic Site was being degraded as a result of poor management (Bates 1993). After negotiation between NSW NPWS the Historic Site was eventually reopened, with changes implemented in accordance with Aboriginal wishes, based on cultural requirements. Yet there continued to be problems. One of the most serious concerns of the Mutawintji community was related to the construction of a walking track. The community was fully consulted as to the location of this track and the nature of its construction. Although the route of the track was as requested by the Aboriginal community, grey 'cracker dust' material was used for track construction:

This upset the Aboriginal people, not only because of the ugly look of it, but because it was made from crushed rock from Broken Hill. Mootwingee is made of orange sandstone but the rock from Broken Hill is an ancient grey rock. One of our main stories features both these places. Broken Hill is where in the dreamtime God Kuluwirru punished all the people who broke the laws and many people were killed and their bodies formed the rocks and their blood formed the silver, lead and zinc. Mootwingee is the place where Kuluwirru tested out the people and found them able to obey his laws and he rewarded them by killing a giant kangaroo to feed them in the 
drought. So to us NPWS was bringing the bodies of the bad people and spilling [them] over one of our most sacred places at Mootwingee. The irony is that this story is told in the Cultural Centre where the footpath started from. NPWS paid a white artist to paint the story on a long mural and NPWS staff wrote up the script from the work of an anthropologist who worked with our elders many years ago. But did they really listen to the story? (Bates 1993:65).

A broader approach to heritage management in this case may have avoided the conflict which unnecessarily marred relationships between the NSW NPWS and the Mutawintji community.

The next example is of more direct relevance to the practice of archaeology within CHM.

In 1993 the consulting firm of Brayshaw McDonald Pty. Ltd. undertook a major site survey and testing program on the Cumberland Plain west of Sydney for the Rouse Hill Infrastructure Project (Stage 1) (McDonald et al. 1994). This cultural heritage program sought to identify areas of archaeological potential and significance within the development project. The focus of the work was essentially landscape-based, rather than site-based. Although several sites were identified from surface survey, the archaeologists realised that, owing to problems of ground surface visibility, relics were likely to be found in other parts of the development area away from the site locales. Twenty-four potential archaeological deposits (PADs) were identified and 14 were tested. Ten of these areas (71\%) were found to contain deposit and some had substantial densities of material.

McDonald et al. (1994:287-288) identified some important implications from these findings for cultural heritage management. They point out that without verification of the presence of relics through excavation these areas could not be protected under the National Parks and Wildlife Act 1974, which protects only tangible relics and not landscapes or areas of heritage potential. '[T]he obligation to investigate PADs is thus indicated as highly desirable archaeologically, although not required legislatively' (McDonald et al. 1994:287).

If an appropriate strategy [for managing PADs] is achieved which satisfies the developer's statutory requirements as well as providing the opportunity for 'better' archaeology, then significant progress will be made by cultural heritage management-based archaeology in contributing to the broader progress of the discipline in this country (McDonald et al. 1994:288).

Significant progress will also be made in narrowing the gap between archaeological and Aboriginal concerns in heritage management.

Of course, broadening the scope of CHM will not necessarily be easy. The current practice of CHM not only suits the main body of practitioners, archaeologists, but also governments. With a focus on individual sites, management is comparatively easily bounded and decisions about recording and salvage, or destruction, can be defined using archaeological arguments.

This paradigm also suits the nature conservation agencies in which cultural heritage is largely situated. The archaeological approach is similar to the scientific basis of broader landscape management. Furthermore, conservationists:

tend also to hold idealised views of prehistoric cultures and what they often call 'traditional' culture, and to denigrate contemporary human activity which does not accord with their idealised perceptions of that culture. As a consequence, they almost always have difficulty with the concept of living Aboriginal people acting as cultural agents (Ellis 1994: 14).

This is particularly so when management extends beyond the individual site, and involves the conservation and management of landscapes. At present, landscape management is the province of nature conservation agencies. Such groups often have problems in recognising that there are no natural systems in Australia; that all landscapes are, in fact, cultural (Ross 1996). While CHM fails to take an interest in landscapes and other broader cultural heritage concerns relating to living traditions,

the seizure of land by Europeans for towns, farms and mines which characterised our early colonial years is in danger of giving way to a new dispossession - the denial of Aboriginal people's rights to land in the name of nature conservation (Toyne and Johnston 1991:9).

\section{A Case Study}

I would like to end this paper by outlining a cultural heritage project which attempts to extend CHM beyond the archaeological paradigm.

In 1995 I received a grant to undertake a cultural heritage planning study on North Stradbroke Island. The project was developed jointly between myself and the Quandamooka Aboriginal Land Council.

Aboriginal people have lived on the land which is now Stradbroke Island for at least 20,000 years (Neal and Stock 1986). On the basis of archaeological evidence from the site of Wallen Wallen Creek, Neal argues that marine exploitation was likely to have been the focus of subsistence activity throughout the site's history (Neal and Stock 1986:621). Evidence from other archaeological sites on Stradbroke Island and elsewhere within Moreton Bay indicates that the Aboriginal subsistence economy was based principally on marine exploitation at least during the late Holocene (Hall and Robins 1984, Walters 1989, 1992, cf. Beaton 1985).

It is difficult to estimate the number of archaeological sites which existed on Stradbroke Island prior to European settlement. Many of the known sites have been destroyed by sand mining and an unknown number of unrecorded sites are also likely to have been similarly 
destroyed (Durbridge 1984, Rowland 1984). There are currently 355 archaeological sites listed for North Stradbroke Island on the QDoE register of sites; 347 of these are shell middens.

Many Aboriginal people living on Stradbroke Island today continue to rely on marine resources as a significant component of their diet. According to members of the Aboriginal community, this reliance on marine foods has persisted with little change or interruption since prehistoric times.

The Aboriginal community on Stradbroke Island is concerned that development projects planned for the Island have had, and will continue to have, a detrimental effect on places of cultural significance to them. Most of these places are not able to be protected by the Cultural Record Landscapes Queensland and Queensland Estate) Act 1987, as they are places and areas which are regarded by most people as being of natural resource significance and are not defined in cultural terms. Management plans for the coastal zones of the Island have generally focussed on the natural heritage value of the areas and ignored the cultural values.

The current project has been formulated as a consequence of these concerns. The aims of the project are:

1. To identify and record areas of North Stradbroke Island which are regarded by the Aboriginal community as culturally significant, focussing on marine resource areas from Dunwich to Amity Point (Figure 1);
2. To document the use of these areas by Aboriginal people both historically and at present, using ethnohistoric accounts and oral history;

3. To develop a plan for the protection and management of areas recognised as having cultural heritage value.

The project is designed to lead to the formulation of options for the better management of important and sensitive cultural heritage areas on Stradbroke Island.

The project is not, of course, archaeology; but it is cultural heritage management.

\section{Acknowledgments}

An earlier draft of this paper was presented at the 1994 AAA Conference at La Trobe University in Melbourne. Several people at that time provided helpful comments and suggestions for the final version of the paper. Comments on a later draft were provided by Bob Ellis, Jo McDonald, Ian Lilley and Sean Ulm. Members of the Quandamooka Aboriginal Land Council on Stradbroke Island were involved in the preparation of the project outlined in the case study. Those most closely involved here were Brian Coghill, Shane Coghill, Dale Ruska, Denise Coghill, Leonie Coghill, Donna Ruska, Darren Byrnes, Alan Perry and Adam Delaney. I thank the Quandamooka Aboriginal Land Council for permission to publish information relating to the Stradbroke Island project.

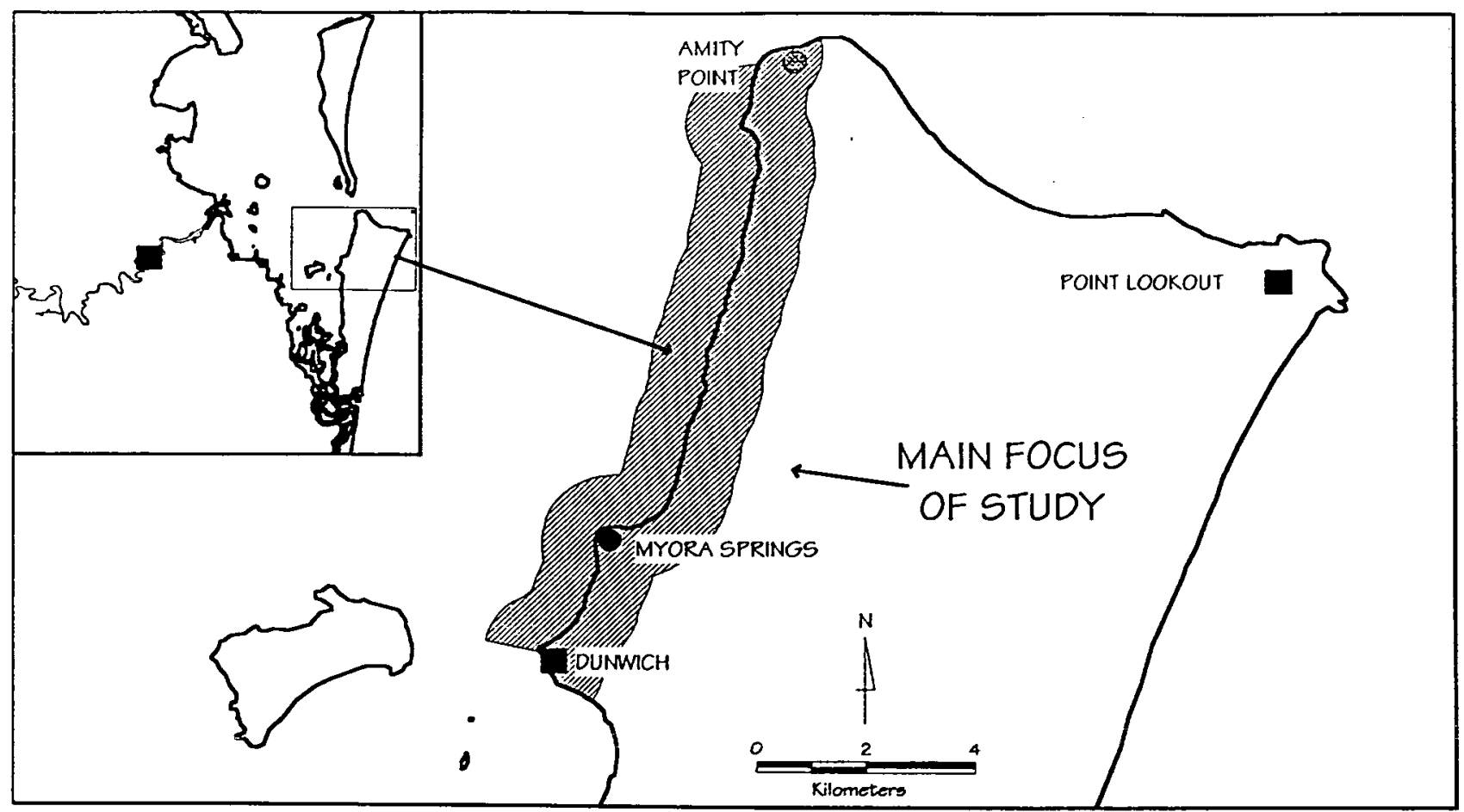

Figure 1. Location of Stradbroke Island study area. 
References Cited

BATES, B. 1993 Mootwingee National Park: a case study. Historic Environment 10:63-66.

BEATON, J.M. 1985 Evidence for a coastal occupation time-lag at Princess Charlotte Bay (North Queensland) and implications for coastal colonization and population growth theories for Aboriginal Australia. Archaeology in Oceania 20:1-20.

BOWDLER, S. 1981 Unconsidered trifles? Cultural resource management, environmental impact statements and archaeological research in New South Wales. Australian Archaeology 12:123-133.

BOWDLER, S. 1983 Aboriginal Sites of the Crowntimber lands of New South Wales. Report to the Forestry Commission of New South Wales.

BOWDLER, S 1988 Repainting Aboriginal rock art. Antiquity 65:517-523.

BYRNE, D. 1991 Western Hegemony on Archaeological Heritage Management. History and Anthropology 5:296-276.

CLEERE, H. 1989 Introduction: the rationale of archaeological heritage management. In $\mathrm{H}$. Cleere (ed.) Archaeological Heritage Management in the Modern World, pp.1-19. Unwin Hyman, London.

CORDELL, J. 1991 Managing Sea Country: Tenure and Sustainability of Aboriginal and Torres Strait Islander Marine Resources. Report on Indigenous Fishing. ESD Fisheries Working Group, Canberra.

CORDELL, J. 1993 Indigenous Peoples' CoastalMarine Domains: Some Matters of Cultural Documentation. Turning the Tide. Conference on Indigenous Peoples and Sea Rights, Darwin.

DURBRIDGE, E. 1984 Aboriginal Middens, North Stradbroke Island. In R.J. Coleman, J. Covacevich, and P. Davie (eds) Focus on Stradbroke: New information on North Stradbroke Island and Surrounding Areas, 1974-1984, pp. 9-15. Boolarong Publications, Brisbane.

ELLIS, R. 1994 Rethinking the paradigm: Cultural Heritage Management in Queensland. Ngulaig 10.

FLOOD, J. 1989 'Tread softly for you tread on my bones': the development of cultural resource management in Australia. In H. Cleere (ed.) Archaeological Heritage Management in the Modern World, pp. 79-93. Unwin Hyman, London.

GEERING, K. and ROBERTS, C. 1993 Current limitations on Aboriginal involvement in Aboriginal site management in centralwest and northwest New South Wales. In J. Birckhead, $\mathrm{T}$. De Lacy, and L. Smith (eds) Aboriginal Involvement in Parks and Protected Areas, pp.207214. Australian Institute of Aboriginal and Torres Strait Islander Studies, Canberra.

GREER, S. 1994 Archaeology in coastal Cape York: an historical backdrop to research. Paper presented to Australian Coastal Archaeology Symposium. 24-26 September 1994, Maroochydore.
HALL, C.M. and McARTHUR, S. 1993 Heritage Management: An Introductory Framework. In C.M. Hall and S. McArthur (eds) Heritage Management in New Zealand and Australia: Visitor Management, Interpretation and Marketing, pp.117. Oxford University Press, Auckland.

HALL, J. and ROBINS, R. 1984 A working model of Moreton Island Prehistory: MRAP Stage I. Queensland Archaeological Research 1:85-94.

HORTON, D. 1987 Editorial Australian Aboriginal Studies 1987/number 2:1.

LANGFORD, R. 1983 Our heritage - your playground. Australian Archaeology 16:1-6.

LEHMAN, G. 1991 Battle for our heritage. Habitat Australia 19:15-16.

LEWIS, H. 1992 The technology and ecology of nature's custodians: anthropological perspectives on Aborigines in national parks. in J. Birckhead, T. De Lacy, and L. Smith (eds) Aboriginal Involvement in Parks and Protected Areas. pp.1528. Australian Institute of Aboriginal and Torres Strait Islander Studies, Canberra.

LEWIS, H.T. 1993 Traditional Ecological Knowledge Some Definitions. In N.M. Williams and G. Baines (eds) Traditional Ecological Knowledge, Wisdom for Sustainable Development, pp.8-12. Centre for Resource and Environmental Studies, Australian National University, Canberra.

McDONALD, J., RICH, E., and BARTON, H. 1994 The Rouse Hill Infrastructure Project (Stage 1) on the Cumberland Plain, western Sydney. In M. Sullivan, S. Brockwell and A. Webb (eds) Archaeology in the North: Proceedings of the 1993 $A A A$ Conference, pp.259-293. North Australia Research Unit (ANU), Darwin.

MAKAGIANSAR, M. 1989 The work of UNESCO. In Protection or Plunder: Safeguarding the Future of our Cultural Heritage, pp. 9ff. Australian Heritage Commission for UNESCO, Australian Government Publishing Service, Canberra.

MOWALJARLI, D. and PECK, C. 1987 Ngarinyin cultural continuity: a project to teach young people the culture including the repainting of Wandjina rock art sites. Australian Aboriginal Studies 1987, Pnumber 2:71-78.

MOWALJARLI, D., VINNICOMBE, P., Ward, G.K. and CHIPPENDALE, C. 1988 Repainting of images on rock in Australia and the maintenance of Aboriginal culture. Antiquity 62:690-696.

MULVANEY, D.J. 1991 Past regained, future lost: the Kow Swamp Pleistocene burials. Antiquity 65:1221.

MUTITJUU COMMUNITY, 1990 An Insight into Uluru. The Mala Walk and the Mutitjulu Walk. Uluru National Park pamphlet. Australian National Parks and Wildlife Service and Mutitjulu Community, Uluru.

NEAL R and STOCK, E. 1986 Pleistocene occupation in the south-east Queensland coastal region. Nature 323:618-621. 
ROGERS, J.L. and McMANAMON, F.P. 1994 The Federal Archaeology Program. CRM: 17(6):

ROWLAND, M.J. 1984 Clean up your own backyard first! Problems and complexities in archaeological resources management - Stradbroke and Moreton Islands. In R.J. Coleman, J. Covacevich, and P. Davie (eds) Focus on Stradbroke: New information on North Stradbroke Island and Surrounding Areas, 1974-1984, pp. 44-53. Boolarong Publications, Brisbane.

ROSS, A. 1994 Traditional hunting in National Parks and the Cultural Heritage Paradigm Ngulaig 11.

ROSS, A. 1996 Landscape as Heritage. in A. Clarke and $\mathrm{L}$. Smith (eds) Issues in management archaeology. Tempus vol 4, St Lucia.

STEVENS, A. 1991 'We come from the land'. Habitat Australia 19:14-15.

SULLIVAN, S. 1986 Aboriginal sites and the law. In A. Ross (ed.) Planning for Aboriginal site management: a handbook for local government planners, pp.52-60. NSW National Parks and Wildlife Service, Sydney
SULLIVAN, S. 1993 Cultural values and cultural imperialism. Historic Environment 10:54-62.

TASK FORCE REPORT 1988 Preliminary Report of Ministerial Task Force on Aboriginal Heritage and Culture. NSW National Parks and Wildlife Service, Sydney.

TOYNE, P. and JOHNSTON, R. 1991 Reconciliation, or the new dispossession? Aboriginal land rights and nature conservation. Habitat Australia 19:810.

WALTERS, I. 1989 Intensified fishery production at Moreton Bay, southeast Queensland, in the Late Holocene. Antiquity 63:215-224.

WALTERS, I. 1992 Antiquity of marine fishing in south-east Queensland. Queensland Archaeological Research 9:35-37.

WILLIAMS, N.M. and BAINES, G. (eds) 1993 Traditional Ecological Knowledge, Wisdom for Sustainable Development. Centre for Resource and Environmental Studies, Australian National University, Canberra. 